\title{
Gall-inducing insects from Atlantic forest of Pernambuco, Northeastern Brazil
}

\author{
Jean Carlos Santos ${ }^{1,4}$, Jarcilene Silva de Almeida-Cortez $z^{2}$ \& Geraldo Wilson Fernandes ${ }^{3}$ \\ ${ }^{1}$ Instituto de Biologia, Universidade Federal de Uberlândia - UFU, \\ CP 593, CEP 38400-902, Uberlândia, MG, Brazil \\ ${ }^{2}$ Departamento de Botânica, Centro de Ciências Biológicas, Universidade Federal de Pernambuco - UFPE, \\ Av. Prof. Moraes Rêgo, s/n, CEP 50670-901, Recife, PE, Brazil \\ ${ }^{3}$ Ecologia Evolutiva e Biodiversidade, Universidade Federal de Minas Gerais - UFMG, \\ CEP 30161-970, Belo Horizonte, MG, Brazil \\ ${ }^{4}$ Corresponding author: Jean Carlos Santos, e-mail: jcsantos@inbio.ufu.br
}

SANTOS, J.C., ALMEIDA-CORTEZ, J.S. \& FERNANDES, G.W. Gall-inducing insects from Atlantic forest of Pernambuco, Northeastern Brazil. Biota Neotrop. 12(3): http://www.biotaneotropica.org.br/v12n3/en/abs tract?inventory+bn00812032012

Abstract: An inventory of gall inducing insects and their host plants in the Atlantic forest of Pernambuco, northeastern Brazil is presented. Samples of galls and their host plants were taken in six fragments of Atlantic forest. One hundred thirty-six different morphotypes of insect galls on 79 host plant species belonging to 35 plant families and 53 genera were recorded. The host plant families most attacked by galling insects were: Lecythidaceae, Myrtaceae, and Nyctaginaceae. The most frequent galling taxa were Diptera of the Cecidomyiidae family (95\%), followed by Lepidoptera and Coleoptera. Galls occurred most frequently on leaves and stems, had globoid and elliptical shapes, green color and absence of trichomes on the external walls. The data indicate an intermediary richness of gall inducing insects when compared to other Brazilian Atlantic forests.

Keywords: biodiversity, Cecidomyiidae, host plants, insect galls, herbivory.

SANTOS, J.C., ALMEIDA-CORTEZ, J.S. \& FERNANDES, G.W. Insetos indutores de galhas da floresta Atlântica de Pernambuco, Nordeste do Brasil. Biota Neotrop. 12(3): http://www.biotaneotropica.org.br/v12n3/ pt/abstract?inventory+bn00812032012

Resumo: Um inventário de insetos galhadores e suas plantas hospedeiras foi realizado para a Mata Atlântica de Pernambuco, Nordeste do Brasil. As galhas e suas plantas hospedeiras foram amostradas em seis fragmentos de Mata Atlântica. Cento e trinta e seis diferentes morfotipos de galhas de insetos em 79 espécies de plantas hospedeiras pertencentes a 35 famílias de plantas e 53 gêneros foram registrados. As famílias de plantas mais atacadas por insetos galhadores foram: Lecythidaceae, Myrtaceae e Nyctaginaceae. O grupo mais frequente de galhador foi Diptera da família Cecidomyiidae (95\%), seguido por Lepidoptera e Coleoptera. Galhas ocorreram mais frequentemente sobre as folhas e caules, possuíam um formato globoso e formas elípticas, de cor verde e ausência de tricomas nas paredes externas. Os dados indicam uma riqueza intermediária de insetos indutores de quando comparado com outras florestas atlânticas brasileiras.

Palavras-chave: biodiversidade, Cecidomyiidae, plantas hospedeiras, insetos galhadores, herbivoria. 


\section{Introduction}

Gall-inducing insects are a special guild of endophytic and specialist plant herbivores (Shorthouse et al. 2005) with most galling species restricted to one specific host plant (see Carneiro et al. 2009a). This species-specific relationship between galling insects and host plants suggests that these herbivores can be used to test broad ecological concepts (Fernandes \& Price 1988, 1991, Price et al. 2004), such as, hypotheses to explain latitudinal and altitudinal patterns (e.g., Fernandes \& Price 1988, Carneiro et al. 2005). A study on global richness of gall-inducing insects estimated the existence of 21,000 to 211,000 species (see Espírito-Santo \& Fernandes 2007). This inaccuracy is probably due to the lack of more studies throughout the many vegetation types and biomes around the globe.

In the Brazilian Atlantic Forest, studies addressing inventories of galling insects have been concentrated in south and southeastern regions of Brazil (e.g. Fernandes et al. 2001, Maia 2005, Dalbem \& Mendonça 2006, Fernandes \& Negreiros 2006, Mendonça 2007, Moreira et al. 2007, see also the Brazilian Atlantic costal ecosystem called restinga, Maia 2001, Oliveira \& Maia 2005, Maia \& Oliveira 2010). Up to the present date, only two local studies (see Fernandes et al. 2009, Silva et al. 2011) reported insect gall richness in the northeastern Brazilian Atlantic Forest, an important area of endemism [Pernambuco Center of Endemism (sensu Silva \& Casteleti 2003)]. Therefore, we present the inventory of galling insects and their host plants in the Atlantic forest of Pernambuco as an attempt reduce the lack of knowledge of the gall inducer insects in this region.

\section{Materials and Methods}

Study area - This study was conducted in six fragments of Atlantic forests in the state of Pernambuco, Brazil, specifically in the Reserva Ecológica de Saltinho (city of Tamandaré) ( $8^{\circ} 43^{\prime} 30^{\prime}$ ' S and $35^{\circ}$ $10^{\prime} 40^{\prime}$ W), Parque Estadual de Dois Irmãos (city of Recife) ( $8^{\circ} 7^{\prime}$ $30^{\prime}$ S and $34^{\circ} 52^{\prime} 30^{\prime}$ W), Reserva Ecológica de Carnijó - Reserva Particular do Patrimônio Natural (RPPN) de Carnijó (city of Moreno) (08 08' 42" S and 35 04 ' 34" W), Reserva Ecológica Mata de Duas Lagoas (city of Cabo de Santo Agostinho) ( $8^{\circ} 18^{\prime} 16^{\prime \prime} \mathrm{S}$ and $34^{\circ} 58^{\prime}$ $17^{\prime}$ W), Refúgio Ecológico Charles Darwin (city of Igarassu) $\left(7^{\circ}\right.$ $48^{\prime} 37^{\prime \prime} \mathrm{S}$ and $34^{\circ} 27^{\prime} 25^{\prime \prime} \mathrm{W}$ ), and Engenho Monjolo (city of Abreu e Lima) ( $7^{\circ} 54^{\prime} 32^{\prime \prime} \mathrm{S}$ and $34^{\circ} 57^{\prime} 25^{\prime} \mathrm{W}$ ). These areas were chosen arbitrarily to cover the maximum of environmental heterogeneity in the Atlantic Forest state of Pernambuco (Figure 1).

Sampling galling insect richness - The Brazilian Atlantic Forest were investigated for galls over a period of seven months from January to September of 2008, once for each area over the sample period. In each site, galling insect richness were sampled by two people following the adapted methodology of random walking (see Julião et al. 2002, Fernandes \& Negreiros 2006), where instead of an hour, five hours were spent in each area (total hours

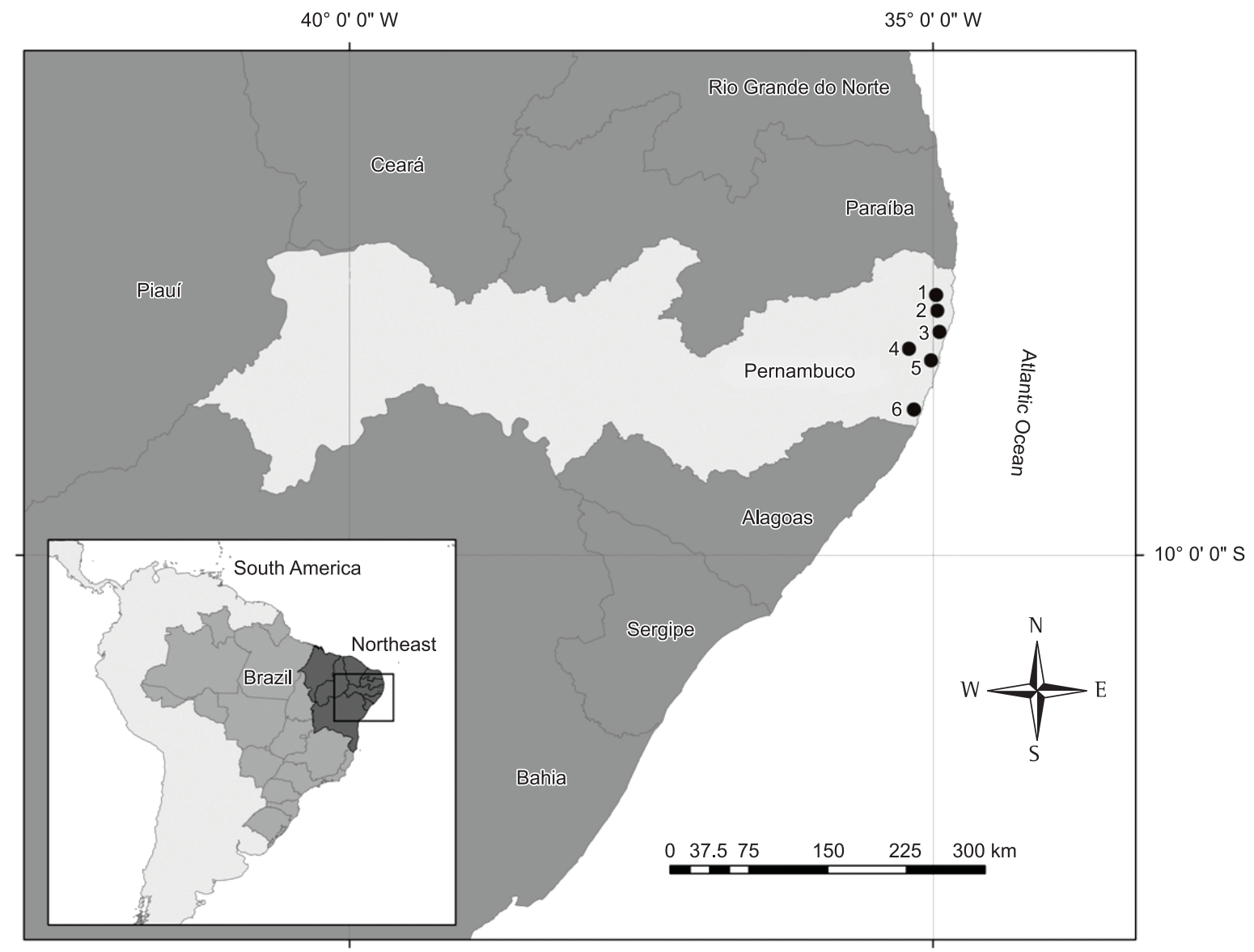

Figure 1. Location of the studied sites of Atlantic forests (number) in Pernambuco state (detail), northeast region (light grey) of Brazil (dark grey): 1 - Refúgio Ecológico Charles Darwin; 2 - Engenho Monjolo; 3 - Parque Estadual Dois Irmãos; 4 - Reserva Particular do Patrimônio Natural (RPPN) de Carnijó; 5 - Reserva Ecológica Mata de Duas Lagoas; 6 - Reserva Ecológica de Saltinho. 
of survey $=30$ hours). To maximize the sampling of richness, a distance of at least $500 \mathrm{~m}$ was established among the sites sampled inside the areas (Fernandes \& Price 1988). All plant organs, except root, were investigated, and each gall and host plants (up to $3 \mathrm{~m}$ high) found were collected, placed into plastic bags, and then taken to a laboratory for photographic registration and description of the external morphology of the galls. Host plants were identified into morphospecies in the field, and later at the species level in the in the Herbarium Geraldo Mariz of the Universidade Federal de Pernambuco (UFPE). The classification of species of host plants followed the system proposed by Angiosperm Phylogeny Group III (Angiosperm... 2009), and the authors and scientific host plant names were checked in the Plantminer, a web tool designed to check seed plants species data (Carvalho et al. 2010). Voucher specimens were deposited in a reference collection do Museu de Biodiversidade do Cerrado (MBC) of Universidade Federal de Uberlândia (UFU).

In this study, the gall morphospecies was identified based upon their external morphology in combination with their host plant species, because, in general, $95 \%$ species of Cecidomyiidae induce a gall on a specific tissue of a certain plant species (Carneiro et al. 2009a). Therefore, the gall morphotypes were considered as true species (see also Coelho et al. 2009). The use of gall morphotype as surrogate of galling species richness is acceptable both ecologically and taxonomically (see Carneiro et al. 2009a) and it has been used in several studies in different ecosystems (e.g. Price et al. 1998, Cuevas-Reyes et al. 2004, Fernandes \& Negreiros 2006, Moreira et al. 2007, Carneiro et al. 2009b, Coelho et al. 2009). Therefore, galls were characterized as reported by Fernandes \& Price (1988): host plant species, number of types of galls by host plant, type of host tissue attacked, shape of galls, color of galls, presence or absence of pubescence, and number of chambers in the gall, occurrence on the galled organ: isolated or grouped/coalescent. A list only with the likely inducers of galls was chosen to be showed because many galls were naturally damaged during the study period, without the presence of the inducing larvae, or parasitized.

\section{Results}

Altogether 136 morphologically distinct types of insect galls were found in the Brazilian Atlantic Forest of Pernambuco. These galls were found on 79 species of host plants belonging to 35 families and 53 genera (Table 1, Figure 2). The greatest richness of galling insects was found in the Reserva Ecológica de Saltinho (59 morphospecies), followed by Parque Estadual de Dois Irmãos (50 morphospecies), Reserva Particular de Carnijó (46 morphospecies), Reserva Ecológica Mata de Duas Lagoas (17 morphospecies), Refúgio Ecológico Charles Darwin (15 morphospecies), and Engenho Monjolo with 13 morphospecies.

Compiling the results from all areas, the majority of galls induced by insects belonged to the family Cecidomyiidae (94.85\%) (Diptera), followed by Lepidoptera $(1.47 \%)$, and Coleoptera $(0.74 \%)$, while $2.94 \%$ were undetermined. The host plant families with the largest number of galling species were: Lecythidaceae, Myrtaceae, and Nyctaginaceae, with $6.62 \%$ (9 morphotypes) each; Burseraceae with $5.88 \%$ (8 morphotypes); Clusiaceae, Fabaceae, Lauraceae, Melastomataceae and Polygonaceae with 5.15\% (7 morphotypes) each; and Rubiaceae with 4.41\% (6 morphotypes) (Table 2). Together these plant families supported approximately $56 \%$ ( 76 morphotypes) of all galls found. The host plant families with the larger number of host plant species were: Myrtaceae with $8.86 \%$ ( 7 species); Polygonaceae with $7.59 \%$ (6 species); Melastomataceae with $6.33 \%$ (5 species); and Fabaceae, Lauraceae, Rubiaceae with 5.06\% (4 species) each (Table 2). Together these plant families supported approximately $38 \%$ (30 species) of all host plants found. The genera with the largest number of gall morphotypes were: Guapira (nine), Protium (seven), and Coccoloba, Miconia, Ocotea, and Eschweilera with six morphotypes each. Most galls were induced on leaves (74.26\%) and stems (19.85\%). The most frequent shape of galls was globoid (29.41\%) followed by the elliptical shape (20.59\%). Ninetyone percent of galls were glabrous, $66.18 \%$ were predominantly green, while $69.12 \%$ did not form clusters.

\section{Discussion}

This study represented an important contribution to the understanding on the galling insect guild distribution in the Brazilian Atlantic Forest of northeast Brazil. A comparison of present study with that from other areas of Brazilian Atlantic Forests showed the richness of the insect galls in the Brazilian Atlantic Forest of Pernambuco (136 morphospecies) was intermediary. The highest diversity (282 morphospecies) was reported by Mendonça (2007) in the Brazilian Atlantic Forest and Pampas of south Brazil and Fernandes et al. (2001) that reported on 273 galling species in several areas of Brazilian Atlantic Forest of the southeast Brazil. To Atlantic Forest in northeastern Brazil, Silva et al. (2011) reported 50 morphospecies along a secondary successional gradient, and Fernandes et al. (2009) reported 32 morphospecies in an urban remnant. Mendonça (2007) argues that the result of highest diversity of insect galls is in function of larger plant families which have more galls, such as Asteraceae. This is in agreement with the hypothesis proposed by Fernandes (1992) in which the higher richness of galling insects should be found on the most speciose host families, the plant richness hypothesis. One likely explanation for the low richness of galling insects in comparison to other forests of the southern Brazilian Atlantic Forest is the fact that the Brazilian Atlantic Forest in the north of the São Francisco River (e.g. Pernambuco's forest) have lower species richness of plants species (Tabarelli et al. 2006) in comparison with other Atlantic forests. Other likely explanation is that most of the remaining forests studied are small and have strong changes in floristic composition and structure due to edge effects and fragmentation habitat (see Tabarelli et al. 2005), reducing the availability of host plants for galling insects and, therefore, reducing galling richness too. Otherwise, many factors, e.g. historical factors, could also be important in explaining the results in this study. Unfortunately, the low number of studies does not permit broader generalizations. More sampling of galls at local and regional scales are needed in order to verify the existence of a regional pattern or even to make generalizations on the differences between northern and southern areas of Brazilian Atlantic Forest based on the diversity patterns of galling insects.

With the majority of galls induced by insects belonged to the family Cecidomyiidae (94.85\%), the results of this study also reinforce the importance of the family Cecidomyiidae as the major taxonomic group among galling in the Neotropical region, accounting for more than $90 \%$ of gall morphotypes (Carneiro et al. 2009a). The composition of the main families of host plants was also distinct from that found in other studies in Atlantic Forest (see Fernandes et al. 2001, Dalbem \& Mendonça 2006, Fernandes \& Negreiros 2006, Mendonça 2007, Moreira et al. 2007, Santos et al. 2011). For instance, in Brazilian Atlantic Forest remnants of Minas Gerais State the families with more galling were Asteraceae, Myrtaceae, Bignoniaceae and Melastomataceae (Fernandes et al. 2001), and in Atlantic Forest from southern Brazil the families with more galling were Asteraceae, Myrtaceae and Sapindaceae (Mendonça 2007). To other studies in the Atlantic Forest from northeast Brazil, the most important plant families were Melastomataceae followed by 


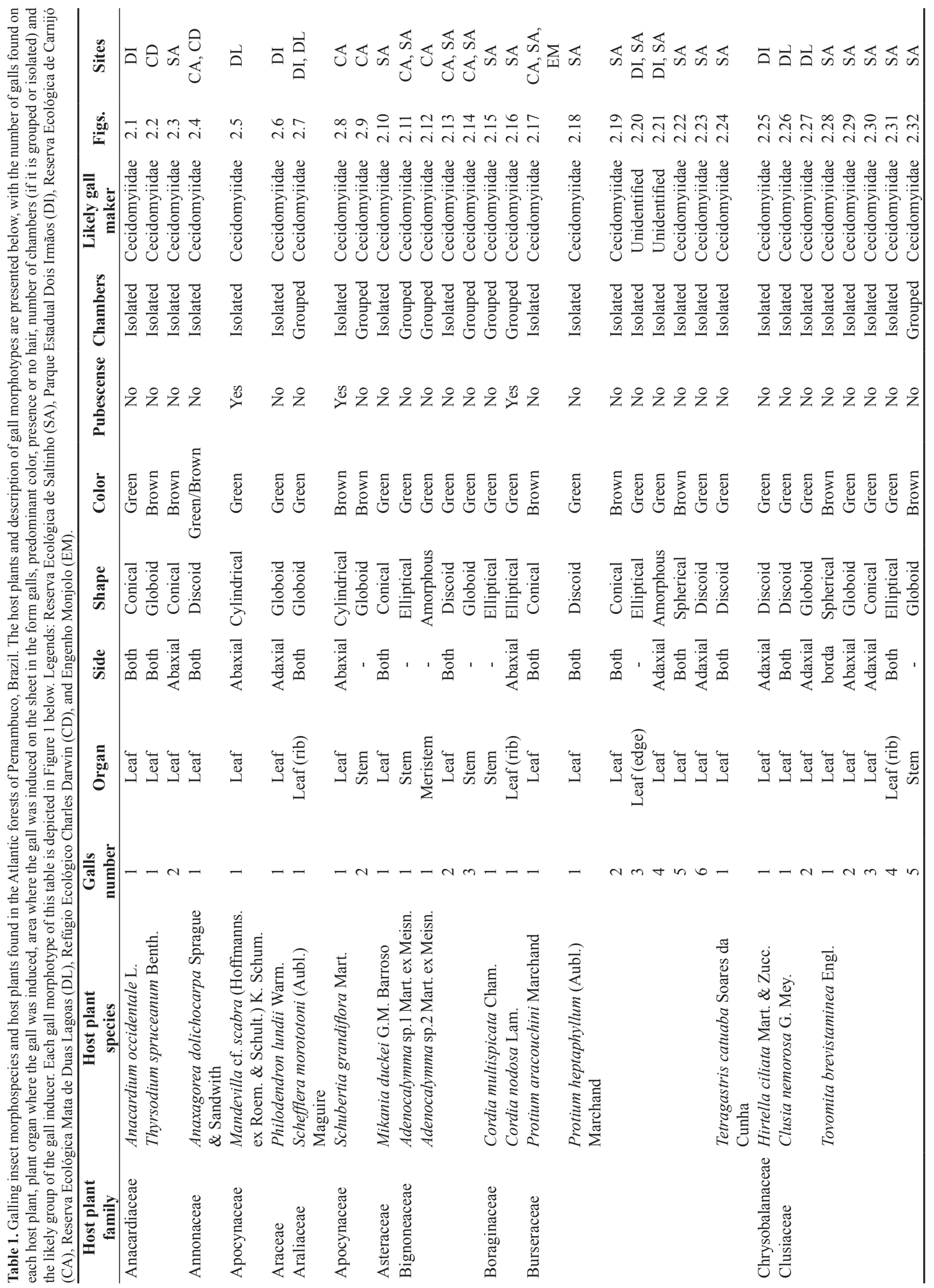




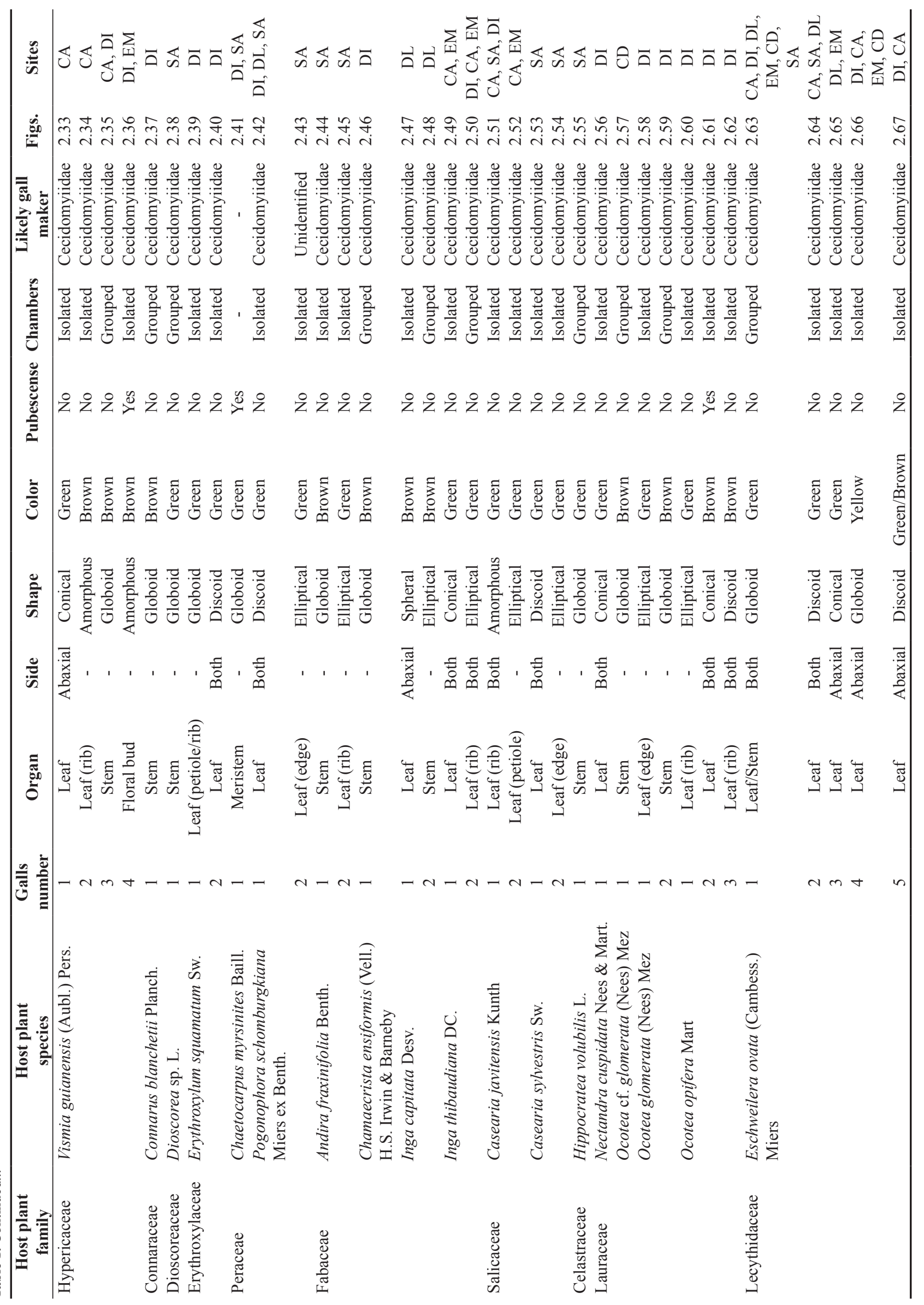




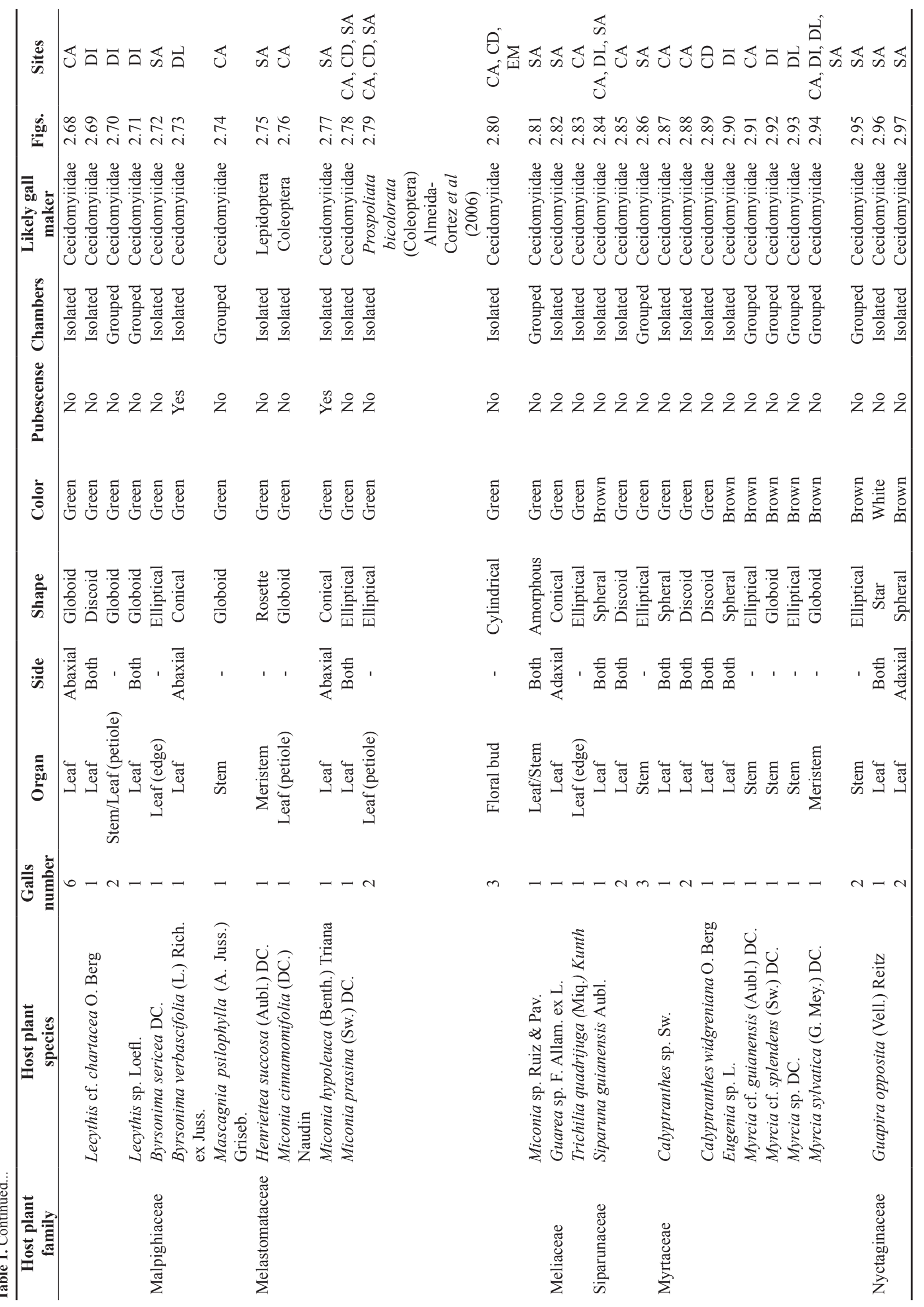




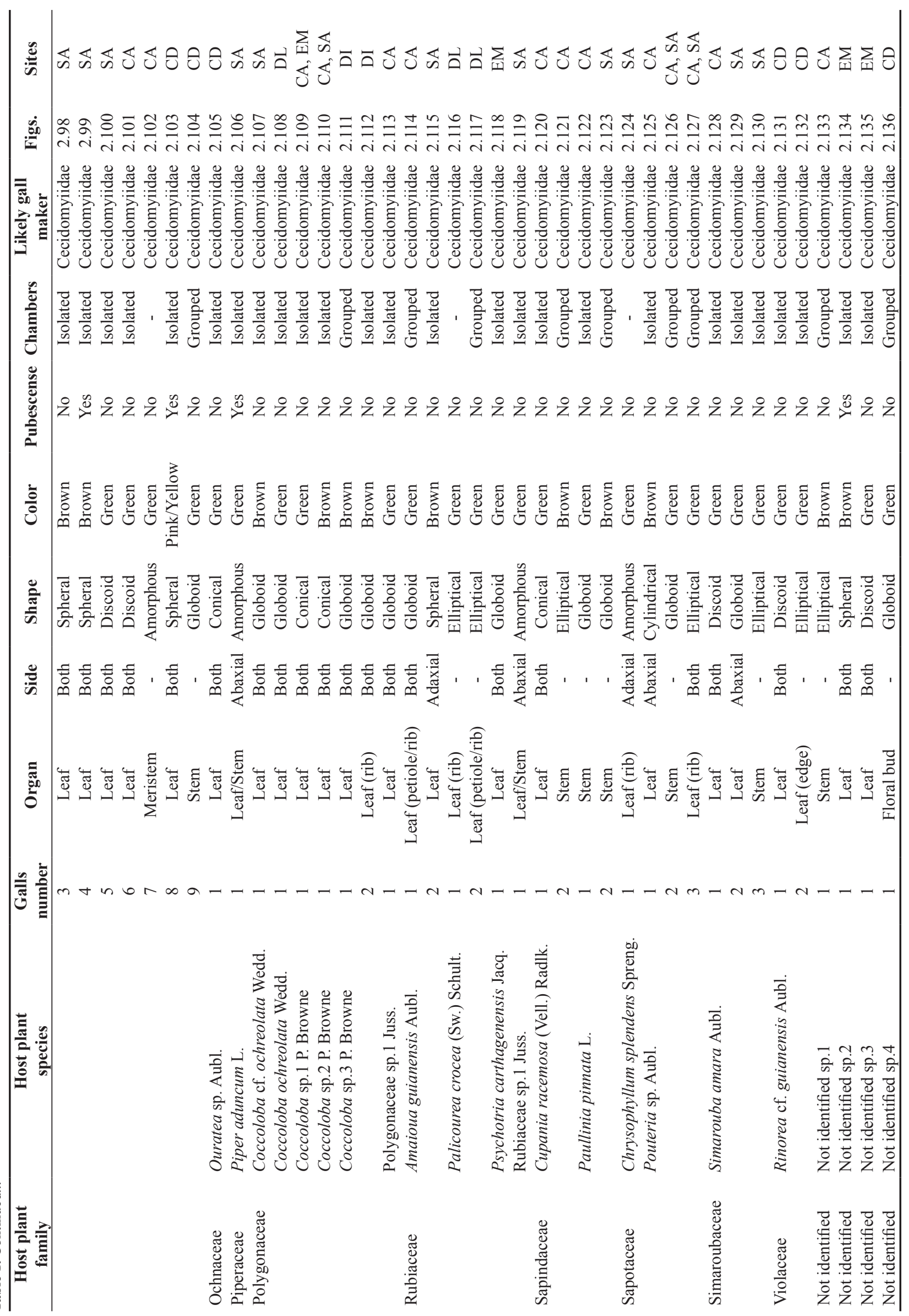



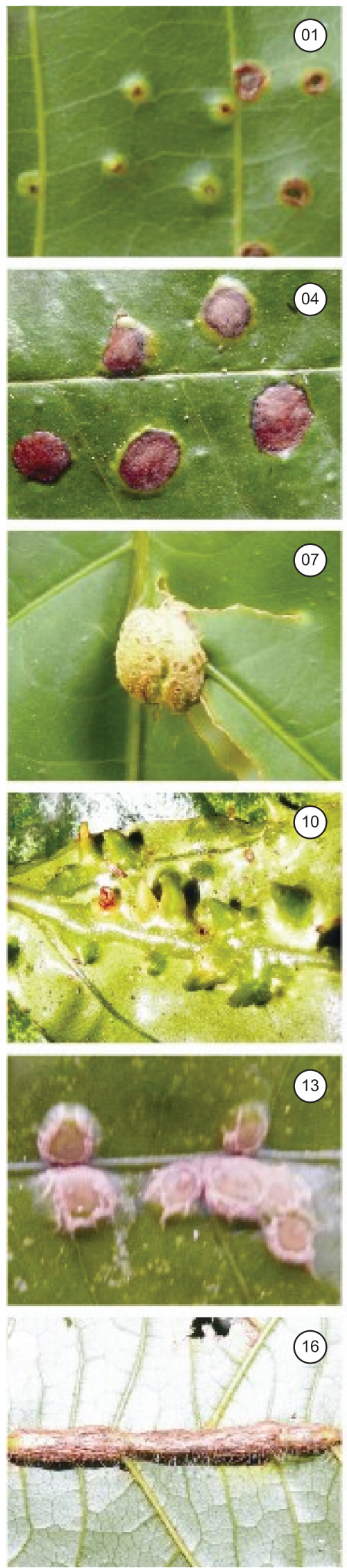
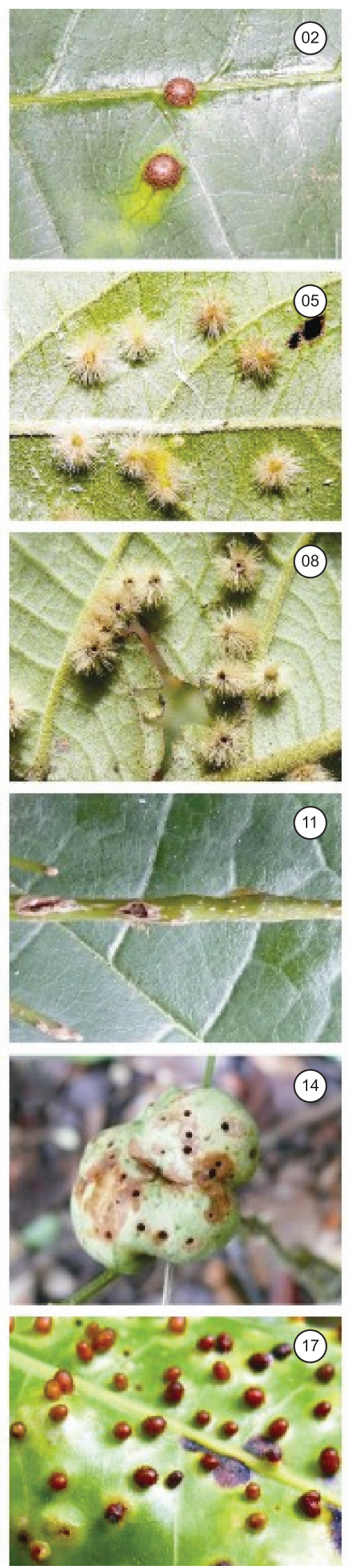

(03)
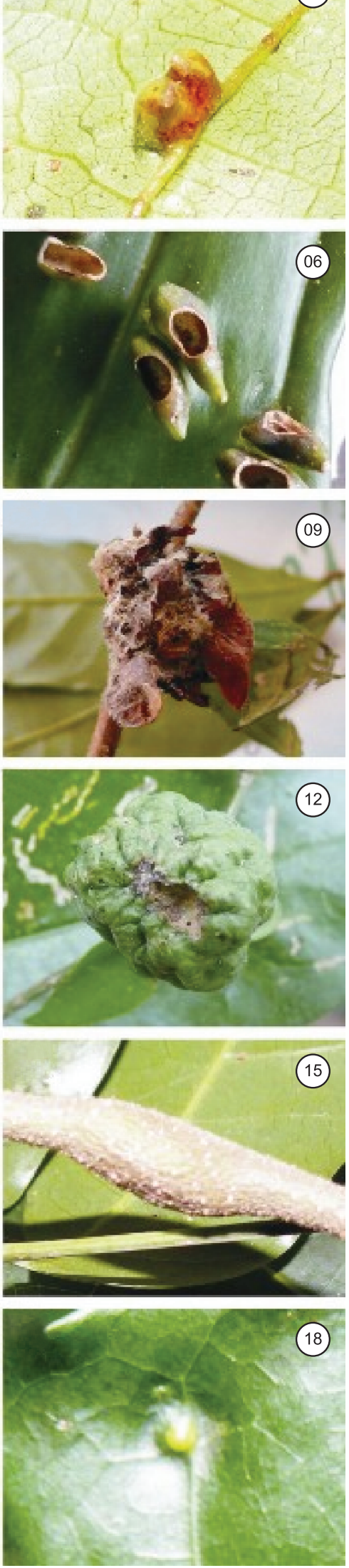

Figure 2. Galling insect morphospecies in Atlantic forests of Pernambuco, Brazil. 1 - Anacardium occidentale; 2 and 3 - Thyrsodium spruceanum; 4 - Anaxagorea dolichocarpa; 5 - Mandevilla cf. scabra; 6 - Philodendron lundii; 7 - Schefflera morototoni; 8 and 9 - Schubertia grandiflora; 10 - Mikania duckei; 11 - Adenocalymma sp.1; 12-14 - Adenocalymma sp.2; 15 - Cordia multispicata; 16 - Cordia nodosa; 17 - Protium aracouchini; 18 - Protium heptaphyllum; 

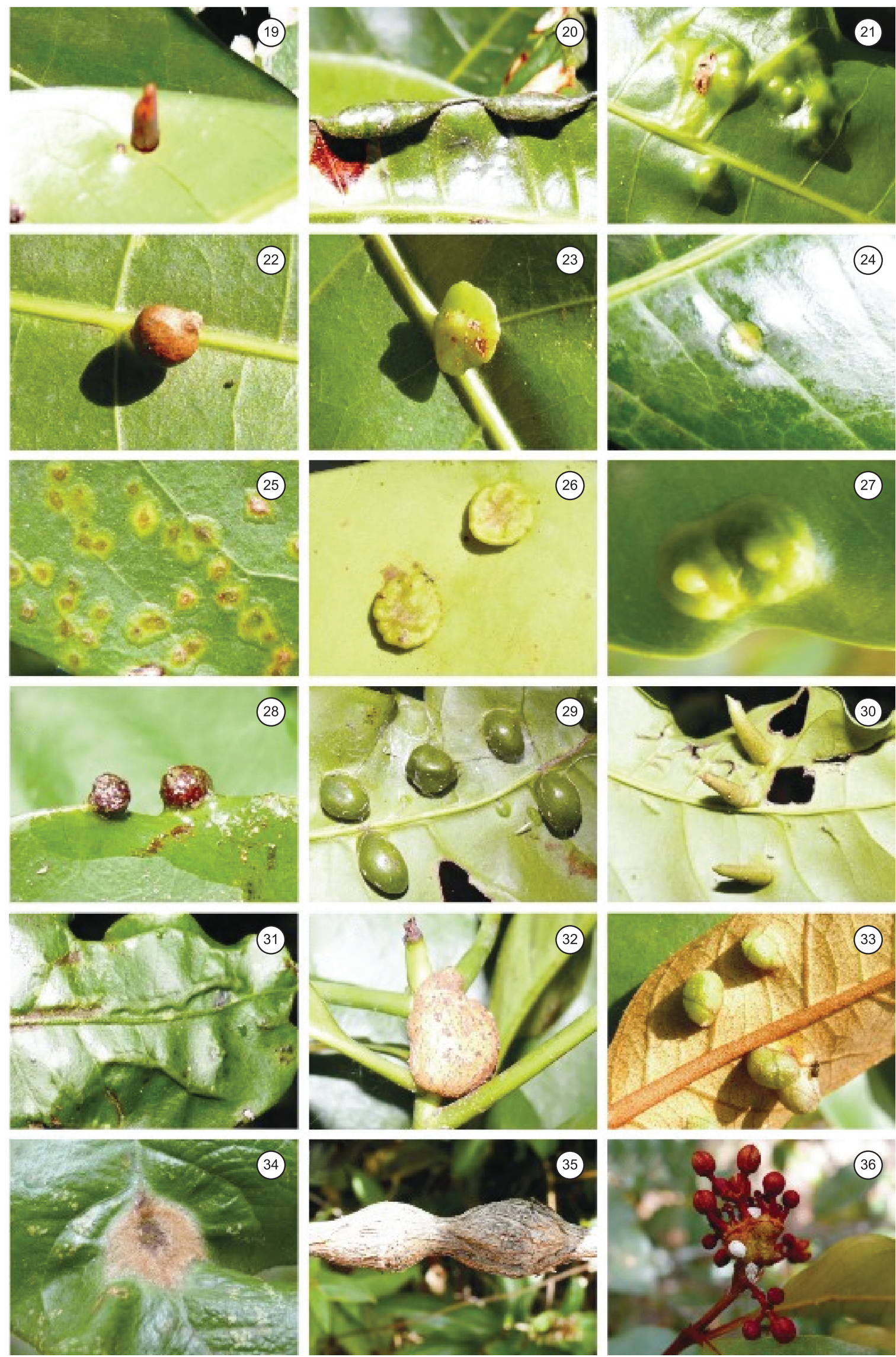

Figure 2. 19-23 - Protium heptaphyllum; 24 - Tetragastris catuaba; 25 - Hirtella ciliata; 26 and 27 - Clusia nemorosa; 28-32 - Tovomita brevistaminea; 24 - Tetragastris catuaba; 25 - Hirtella ciliata; 26 and 27 - Clusia nemorosa; 28-32 - Tovomita brevistaminea; 33-36 - Vismia guianensis; 

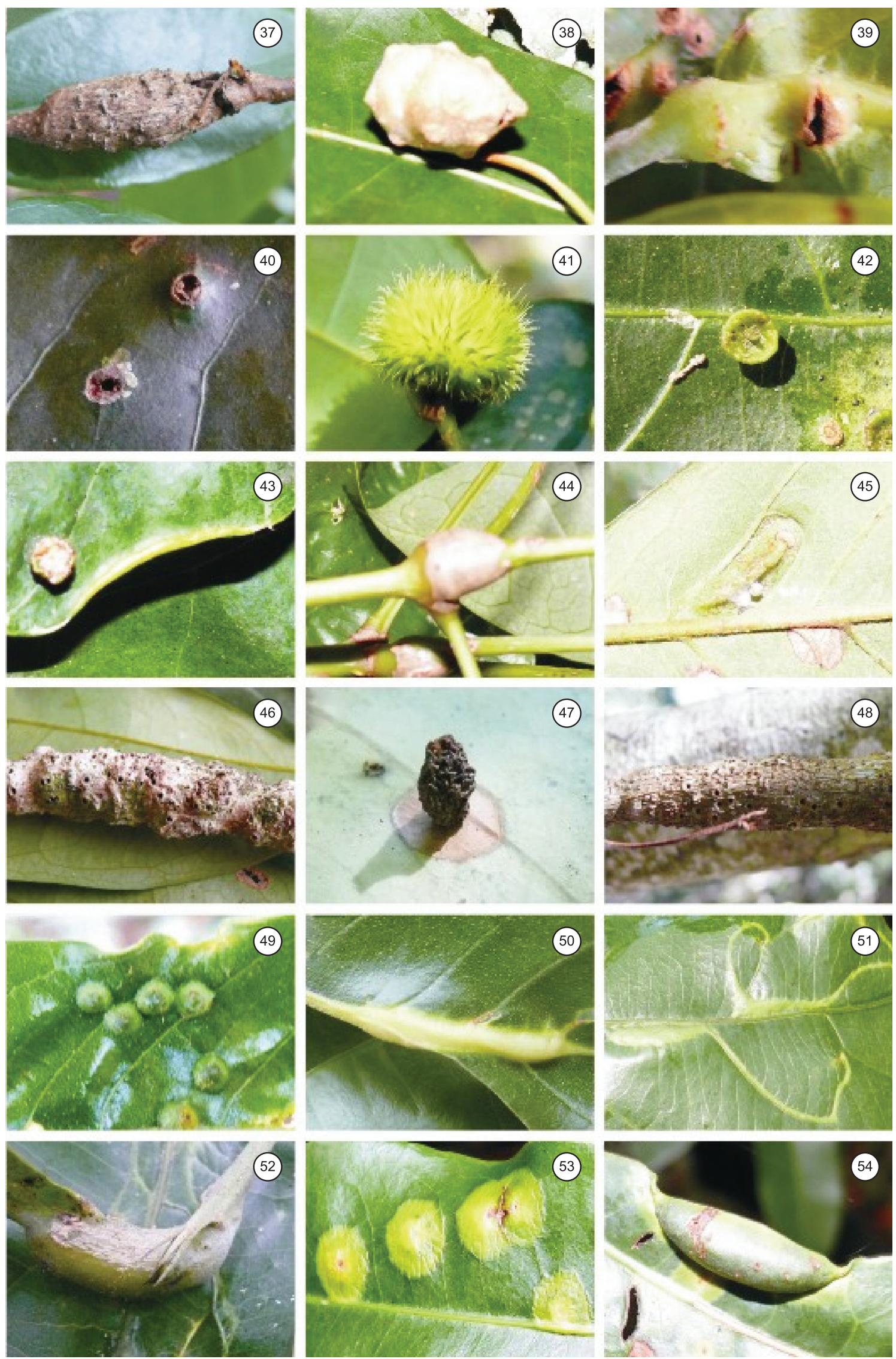

Figure 2. 37 - Connarus blanchetii; 38 - Dioscorea sp.; 39 and 40 - Erythroxylum squamatum; 41 - Chaetocarpus myrsinites; 42 and 43 - Pogonophora schomburgkiana; 44 and 45 - Andira fraxinifolia; 46 - Chamaecrista ensiformis; 47 and 48 - Inga capitata; 49 and 50 - Inga thibaudiana; 51 and 52 - Casearia javitensis; 53 and 54 - Casearia sylvestris; 

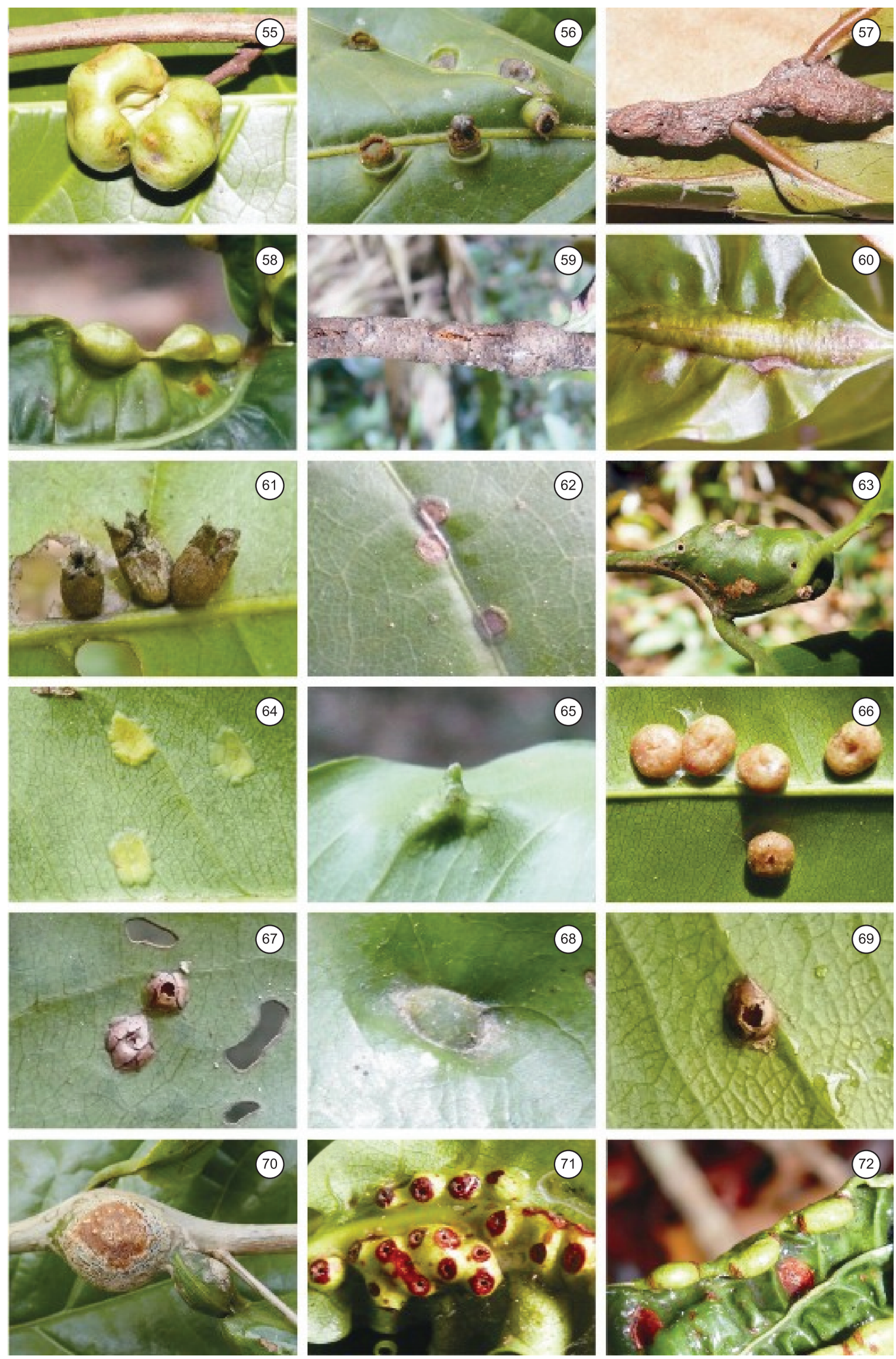

Figure 2. 55 - Hippocratea volubilis; 56 - Nectandra cuspidata; 57 - Ocotea cf. glomerata; 58 and 59 - Ocotea glomerata; 60-62 - Ocotea opifera; 6368 - Eschweilera ovata; 69 and 70 - Lecythis cf. chartacea; 71 - Lecythis sp.; 72 - Byrsonima sericea; 

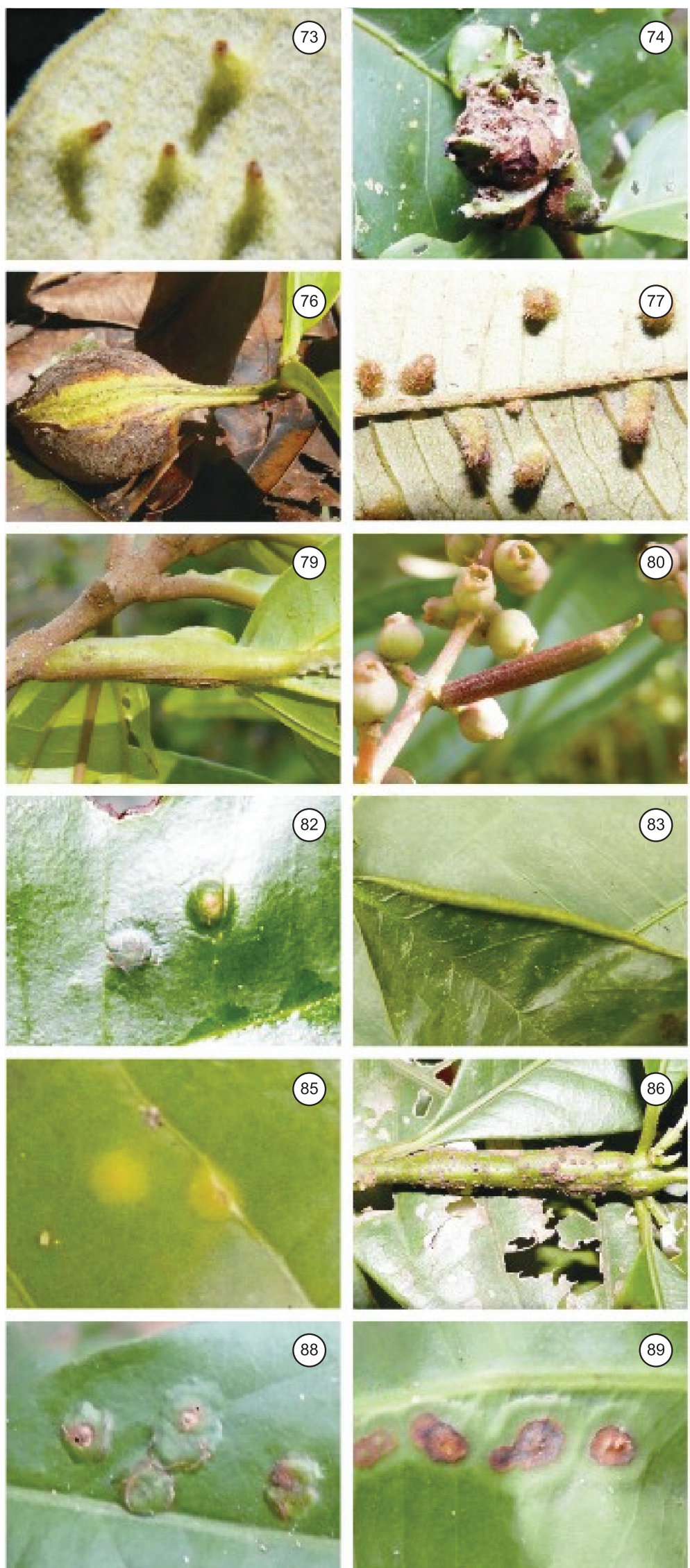
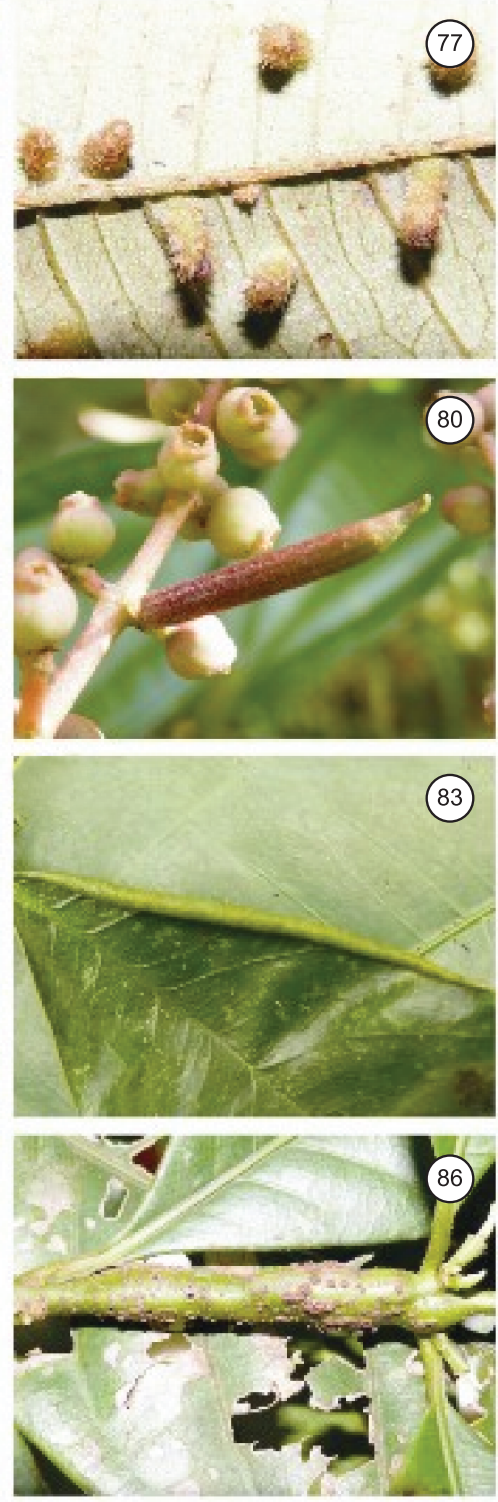

(89)

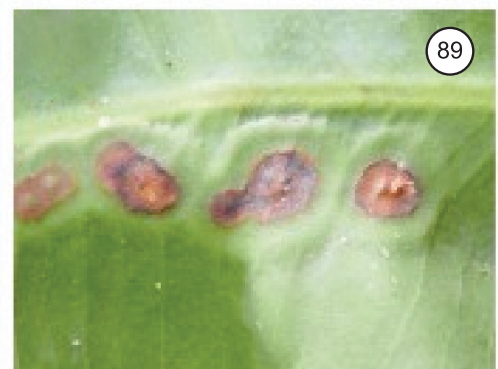

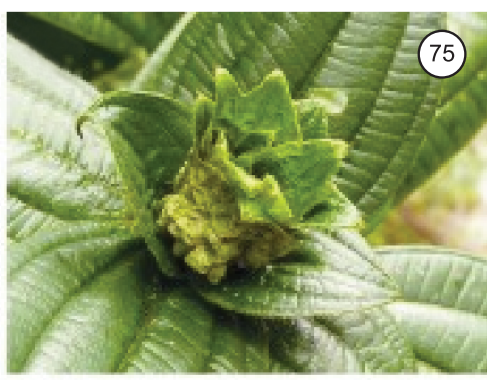
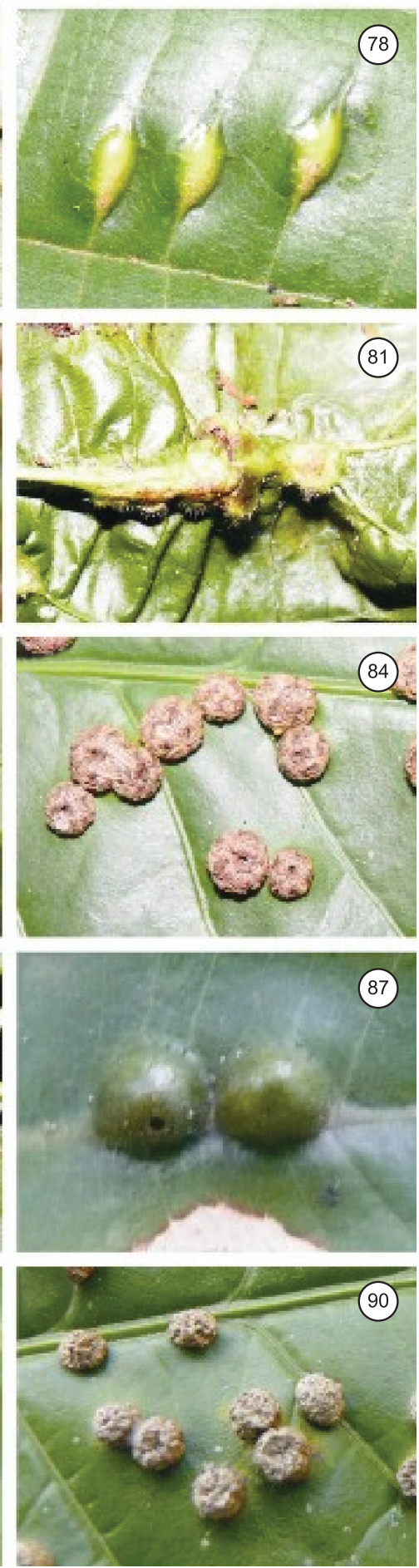

Figure 2. 73 - Byrsonima verbascifolia; 74 - Mascagnia psilophylla; 75 - Henriettea succosa; 76 - Miconia cinnamomifolia; 77 - Miconia hypoleuca; 78 80 - Miconia prasina; 81 - Miconia sp.; 82 - Guarea sp.; 83 - Trichilia quadrijuga; 84-86 - Siparuna guianensis; 87 and 88 - Calyptranthes sp.; 89 - Calyptranthes widgreniana; 90 - Eugenia sp.; 

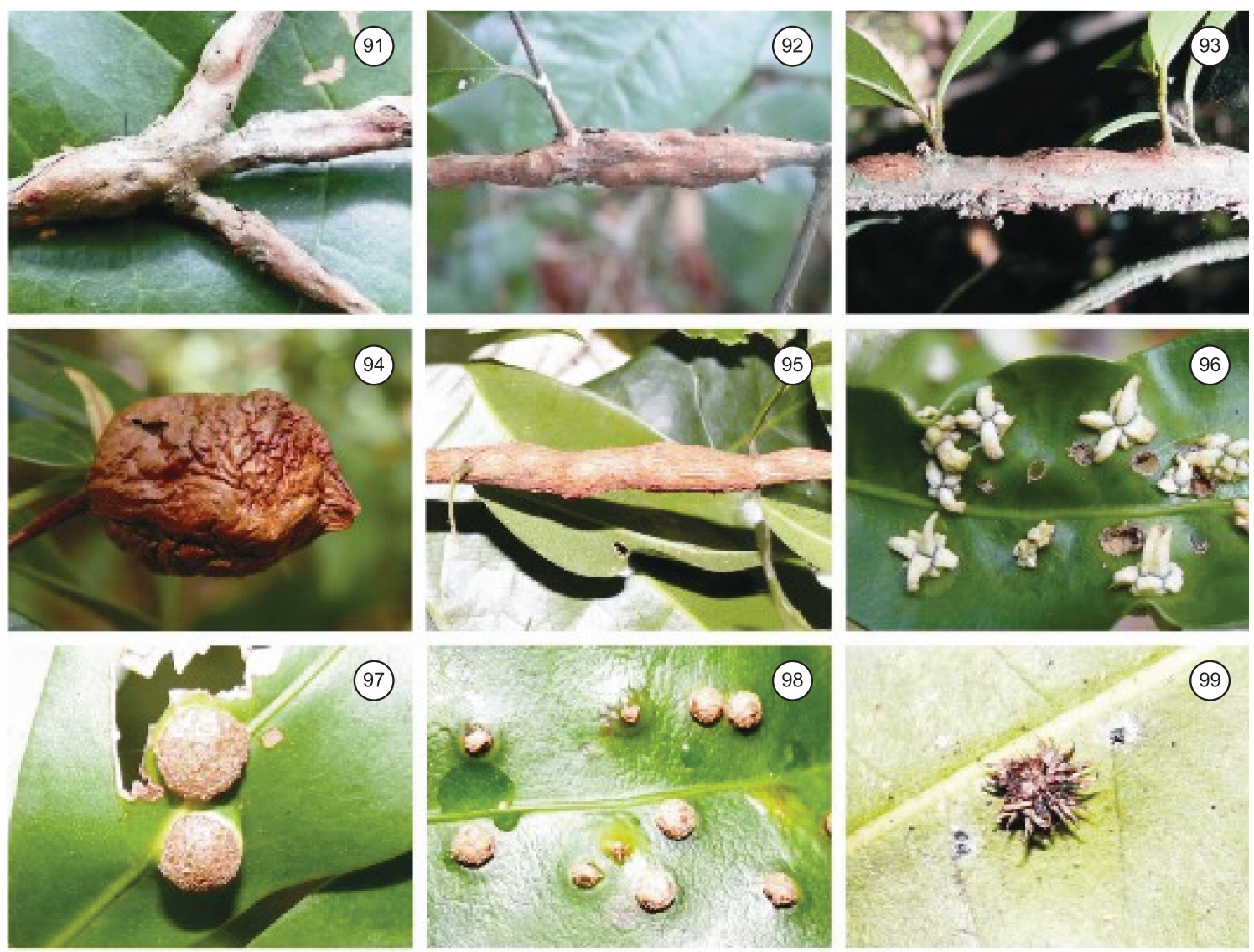

(99)
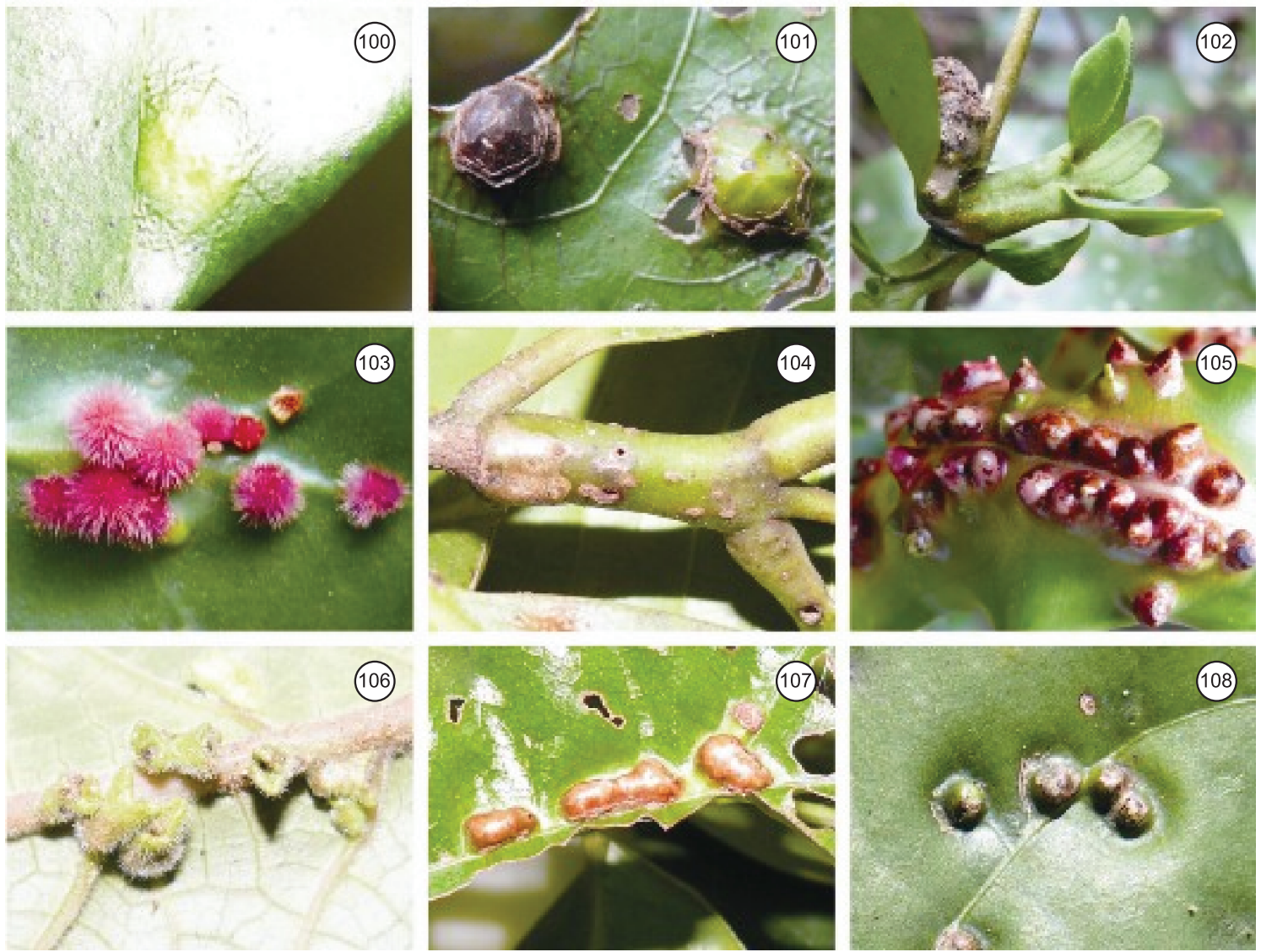

Figure 2. 91 - Myrcia cf. guianensis; 92 - Myrcia cf. splendens; 93 - Myrcia sp.; 94 and 95 - Myrcia sylvatica; $96-104$ - Guapira opposita; 105 - Ouratea sp.; 106 - Piper aduncum; 107 - Coccoloba cf. ochreolata; 108 - Coccoloba ochreolata; 

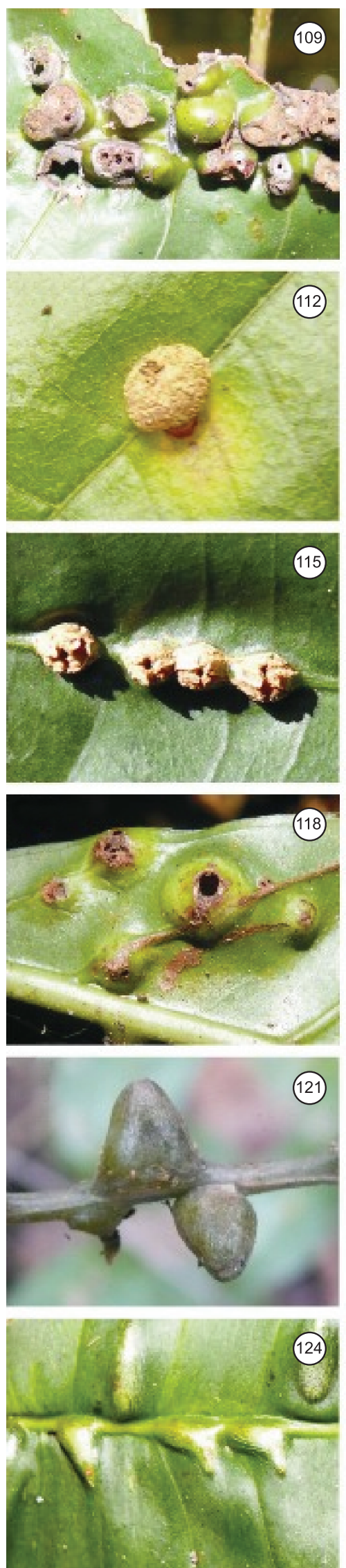
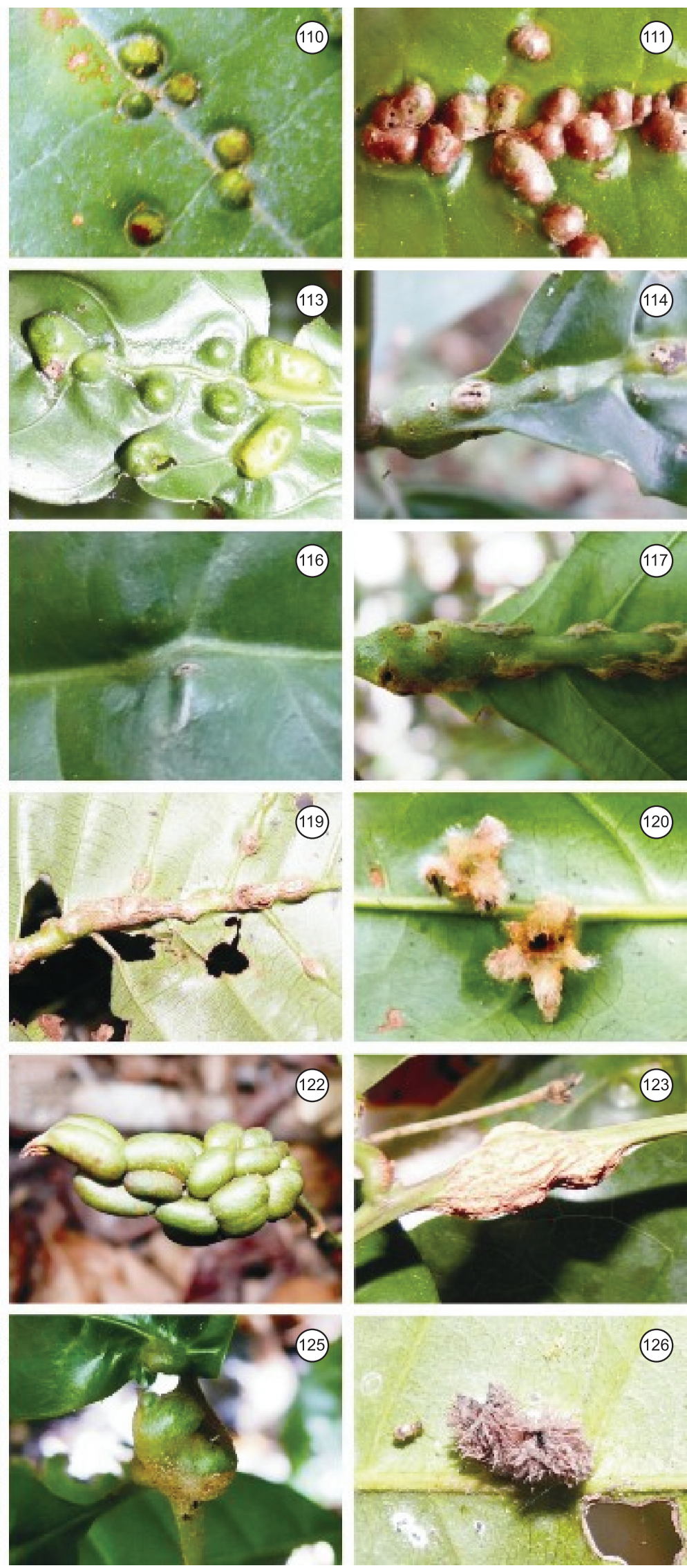

Figure 2. 109 - Coccoloba sp.1; 110 - Coccoloba sp.2; 111 and 112 - Coccoloba sp.3; 113 - Polygonaceae sp.1; 114 and 115 - Amaioua guianensis; 116 and 117 - Palicourea crocea; 118 - Psychotria carthagenensis; 119 - Rubiaceae sp.1; 120 and 121 - Cupania racemosa; 122 and 123 - Paullinia pinnata; 124 - Chrysophyllum splendens; 125-126 - Pouteria sp.; 

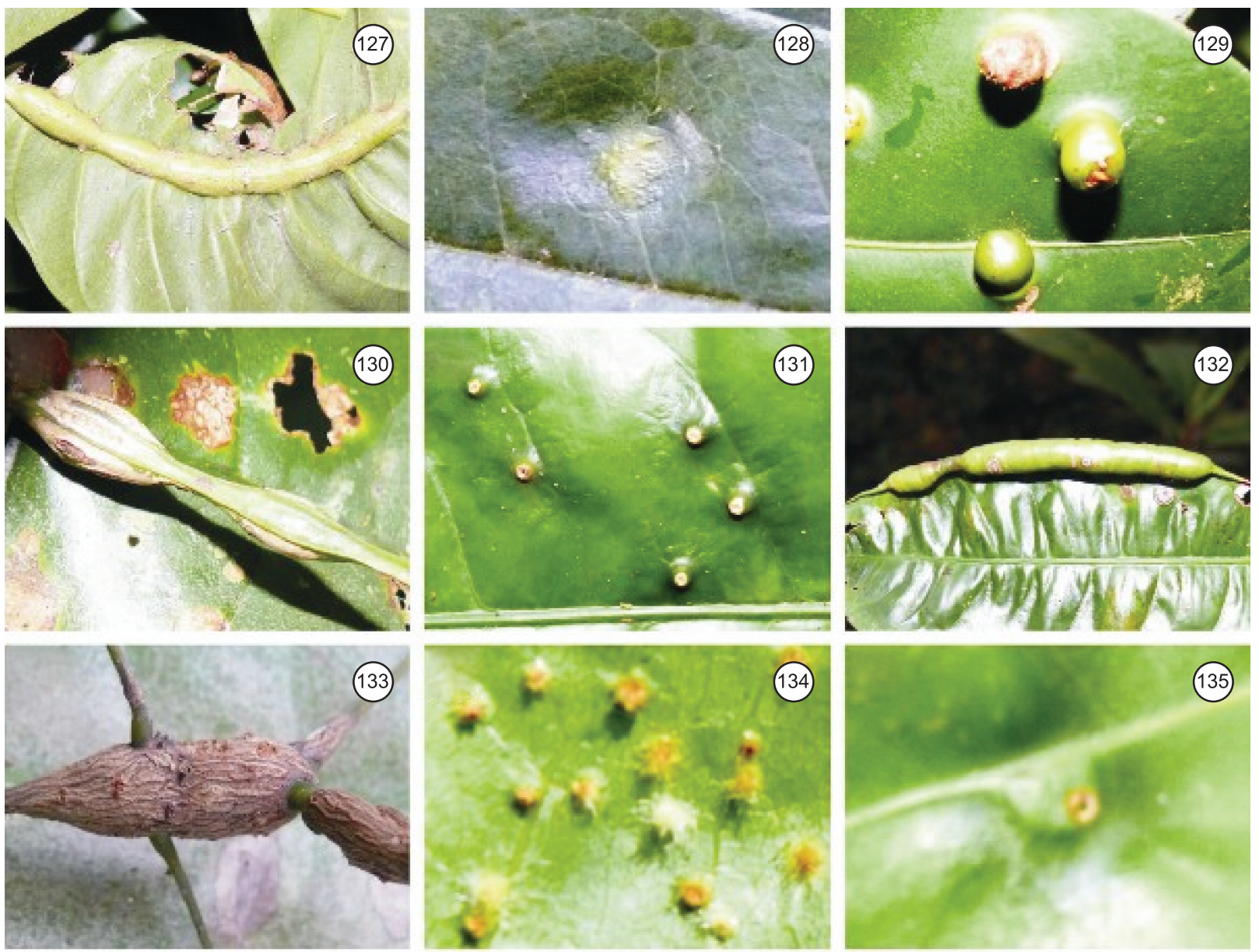

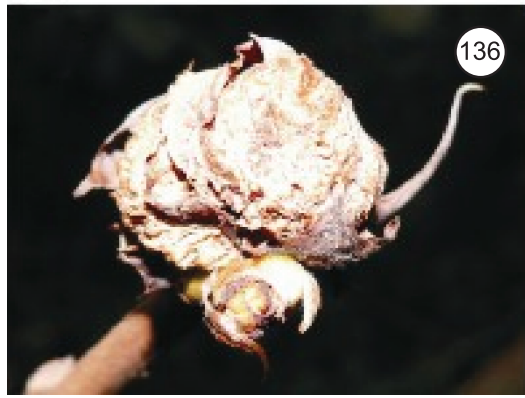

Figure 2. 127 - Pouteria sp.;128-130 - Simarouba amara; 131 and 132 - Rinorea cf. guianensis; 133 - Not identified sp.1; 134 - Not identified sp.2; 135 - Not identified sp.3; 136 - Not identified sp.4. For host plant identification and gall morphotypes description, see also Table 1.

Piperaceae in Usina Serra Grande, Alagoas state (Silva et al. 2011) and Burseraceae, Lecythidaceae, Annonaceaea and Melastomataceae in Parque Estadual de Dois Irmãos, Pernambuco state (Fernandes et al. 2009); while in this study Lecythidaceae, Myrtaceae, Nyctaginaceae, and Burseraceae were the families with more galling insects. This could be the consequence of the size of the host plant families in the region. In addition, as pointed out by some authors (e.g., Fernandes 1992, Fernandes \& Price 1988), the presence of super-hosts can be an important element to determinate the composition of the community of galling insects. In this study, only Guapira opposita (Vell.) Reitz, Eschweilera ovata (Cambess.) Miers and Protium heptaphyllum (Aubl.) Marchand accounted for approximately 15\% (21 morphotypes) of gall morphotypes. Guapira opposita was the host plant with more galling species (nine morphospecies). In other ecosystems, these species also is considered a super-host (Maia 2001, Maia et al. 2008, Maia \& Oliveira 2010). Similar case can be found in savannah areas, where the genus Baccharis is a super-host (Fernandes et al. 1996, Espírito-Santo \& Fernandes 2007).

In relation to shapes, pubescence, occurrence and plants organ attacked, the result obtained in this study correspond to those found by Fernandes et al. (2001) which shows a similarity in the life of this galling strategies for this type of forest. In this study, the galls were globoid and elliptical, glabrous, predominantly green, with one chamber per gall and that induce galls on leaves and stems. Whereas in Fernandes et al. (2001) the galls were elliptical and spherical, glabrous, predominantly green, with one chamber per gall and that induce galls on leaves and stems. 
Table 2. Number species and proportion of galling insect morphospecies and host plants species for each host plant family found in the Atlantic forests of Pernambuco, Brazil.

\begin{tabular}{|c|c|c|c|c|}
\hline \multirow{2}{*}{$\begin{array}{l}\text { Host plant } \\
\text { family }\end{array}$} & \multicolumn{2}{|c|}{$\begin{array}{l}\text { Galling insect } \\
\text { morphospecies }\end{array}$} & \multicolumn{2}{|c|}{$\begin{array}{c}\text { Host plant } \\
\text { species }\end{array}$} \\
\hline & $\begin{array}{c}\text { Number } \\
\text { species }\end{array}$ & Proportion & $\begin{array}{c}\text { Number } \\
\text { species }\end{array}$ & Proportion \\
\hline Anacardiaceae & 3 & 2.21 & 2 & 2.53 \\
\hline Annonaceae & 1 & 0.74 & 1 & 1.27 \\
\hline Apocynaceae & 3 & 2.21 & 2 & 2.53 \\
\hline Araceae & 1 & 0.74 & 1 & 1.27 \\
\hline Araliaceae & 1 & 0.74 & 1 & 1.27 \\
\hline Asteraceae & 1 & 0.74 & 1 & 1.27 \\
\hline Bignoneaceae & 4 & 2.94 & 2 & 2.53 \\
\hline Boraginaceae & 2 & 1.47 & 2 & 2.53 \\
\hline Burseraceae & 8 & 5.88 & 3 & 3.80 \\
\hline Chrysobalanaceae & 1 & 0.74 & 1 & 1.27 \\
\hline Clusiaceae & 7 & 5.15 & 2 & 2.53 \\
\hline Hypericaceae & 4 & 2.94 & 1 & 1.27 \\
\hline Connaraceae & 1 & 0.74 & 1 & 1.27 \\
\hline Dioscoreaceae & 1 & 0.74 & 1 & 1.27 \\
\hline Erythroxylaceae & 2 & 1.47 & 1 & 1.27 \\
\hline Peraceae & 3 & 2.21 & 2 & 2.53 \\
\hline Fabaceae & 7 & 5.15 & 4 & 5.06 \\
\hline Salicaceae & 4 & 2.94 & 2 & 2.53 \\
\hline Celastraceae & 1 & 0.74 & 1 & 1.27 \\
\hline Lauraceae & 7 & 5.15 & 4 & 5.06 \\
\hline Lecythidaceae & 9 & 6.62 & 3 & 3.80 \\
\hline Malpighiaceae & 3 & 2.21 & 3 & 3.80 \\
\hline Melastomataceae & 7 & 5.15 & 5 & 6.33 \\
\hline Meliaceae & 2 & 1.47 & 2 & 2.53 \\
\hline Siparunaceae & 3 & 2.21 & 1 & 1.27 \\
\hline Myrtaceae & 9 & 6.62 & 7 & 8.86 \\
\hline Nyctaginaceae & 9 & 6.62 & 1 & 1.27 \\
\hline Ochnaceae & 1 & 0.74 & 1 & 1.27 \\
\hline Piperaceae & 1 & 0.74 & 1 & 1.27 \\
\hline Polygonaceae & 7 & 5.15 & 6 & 7.59 \\
\hline Rubiaceae & 6 & 4.41 & 4 & 5.06 \\
\hline Sapindaceae & 4 & 2.94 & 2 & 2.53 \\
\hline Sapotaceae & 4 & 2.94 & 2 & 2.53 \\
\hline Simaroubaceae & 3 & 2.21 & 1 & 1.27 \\
\hline Violaceae & 2 & 1.47 & 1 & 1.27 \\
\hline Not identified & 4 & 2.94 & 4 & 5.06 \\
\hline All groups & 136 & 100 & 79 & 100 \\
\hline
\end{tabular}

\section{Acknowledgements}

We thank M. .A. A. Carneiro and two anonymous reviewers for comments of this manuscript. We also thank Mr. Gilcean, C. Magalhães, C. Tavares, M. Honorato, A. Ferreira for field work, A. Aguiar (Patriota) for figure design, ICMBio and the support provided by DCR-FACEPE/CNPq (DCR-0087-2.05/06, APQ-0008-2.05/07), FAPEMIG (APQ-01278-08, CRA 465/07, 122/07) and CNPq (47 2811/2006-1, 30 3352/2010-8).

\section{References}

ANGIOSPERM PHYLOGENY GROUP III - APG III. 2009. An update of the angiosperm phylogeny group classification for the orders and families of flowering plants: APG III. Bot. J. Linn. Soc. 161(2):105-121. http:// dx.doi.org/10.1111/j.1095-8339.2009.00996.x
CARNEIRO, M.A.A., BRANCO, C.S.A., BRAGA, C.E.D., ALMADA, E.D., COSTA, M.B.M., FERNANDES, G.W. \& MAIA, V.C. 2009a Are gall midge species (Diptera: Cecidomyiidae) host plant specialists? Rev. Bras. Entom. 53(3):365-378. http://dx.doi.org/10.1590/S008556262009000300010

CARNEIRO, M.A.A., BORGES, R.X.A., ARAÚJO, A.P.A. \& FERNANDES, G.W. 2009b. Insetos indutores de galhas da porção sul da Cadeia do Espinhaço, MG. Rev. Bras. Entom. 53(4):570-592. http://dx.doi. org/10.1590/S0085-56262009000400007

CARNEIRO, M.A.A., FERNANDES, G.W. \& DE SOUZA, O.F.F. 2005. Convergence in the variation of local and regional galling species richness. Neotrop. Entomol. 34(4):547-553. http://dx.doi.org/10.1590/ S1519-566X2005000400003

CARVAlHO, G.H., CIANCIARUSO, M.V. \& BATALHA, M.A. 2010. Plantminer: a web tool for checking and gathering plant species taxonomic information. Environ. Modell. Softw. 25(6):815-816. http://dx.doi. org/10.1016/j.envsoft.2009.11.014

COELHO, M.S., ALMADA, E.D., FERNANDES, G.W., CARNEIRO, M.A.A., SANTOS, R.M., QUINTINO, A.V. \& SANCHEZ-AZOFEIFA, A. 2009. Gall inducing arthropods from a seasonally dry tropical forest in Serra do Cipó, Brazil. Rev. Bras. Entom. 53(3):404-414. http://dx.doi. org/10.1590/S0085-56262009000300015

CUEVAS-REYES, P., QUESADA, M., HANSON, P, DIRZO, R. \& OYAMA, K. 2004. Diversity of gall-inducing insects in a Mexican tropical dry forest: the importance of plant species richness, life forms, host plant age and plant density. J. Ecol. 92(4):707-716. http://dx.doi.org/10.1111/ j.0022-0477.2004.00896.x

DALBEM, R.V.\& MENDONÇA, M.S. 2006. Diversity of galling arthropods and host plants in a subtropical forest of Porto Alegre, Southern Brazil. Neotrop. Entomol. 35(5):616-624. PMid:17144132. http://dx.doi. org/10.1590/S1519-566X2006000500007

ESPÍRITO-SANTO, M.M. \& FERNANDES, G.W. 2007. How many species of gall-inducing insects are there on earth, and where are there? Ann. Entomol. Soc. Am. 100(2):95-99. http://dx.doi.org/10.1603/00138746(2007)100[95:HMSOGI]2.0.CO;2

FERNANDES, G. W. 1992. Plant family size and age effects on insular gall-forming species richness. Global Ecol. Biogeogr. 2(3):71-74. http:// dx.doi.org/10.2307/2997508

FERNANDES, G.W. \& NEGREIROS, D. 2006. A comunidade de insetos galhadores da RPPN Fazenda Bulcão, Aimorés, Minas Gerais, Brasil Lundiana. 7(2):111-120.

FERNANDES, G.W. \& PRICE, P.W. 1988. Biogeographical gradients in galling species richness: tests of hypotheses. Oecologia. 76(2):161-167. http://dx.doi.org/10.1007/BF00379948

FERNANDES, G.W. \& PRICE, P.W. 1991. Comparisons of tropical and temperate galling species richness: the roles of environmental harshness and plant nutrient status. In Plant-animal interactions: evolutionary ecology in tropical and temperate regions (P.W. Price, T.M. Lewinsohn, G.W. Fernandes \& W.W. Benson, eds.). Wiley \& Sons, New York, p.91-115.

FERNANDES, G.W., CARNEIRO, M.A.A., LARA, A.C.F., ALLAIN, L.A., ANDRADE, G.I., JULIÃO, G.R., REIS, T.C. \& SILVA, I.M. 1996. Galling insects on neotropical species of Baccharis (Asteraceae). Trop. Zool. 9(2):315-332. http://dx.doi.org/10.1080/03946975.1996.10539315

FERNANDES, G.W., JULIÃO G.R., ARAÚJO, R.C., ARAÚJO, S.C., LOMBARDI, J.A., NEGREIROS, D. \& CARNEIRO, M.A.A. 2001 Distribution and morphology of insect galls of the Rio Doce Valley, Brazil. Naturalia 26(3):211-244

FERNANDES, S.P.C., CASTELO-BRANCO, B.P., ALBUQUERQUE, F.A., FERREIRA, A.L.N., BRITO-RAMOS, A.B., BRAGA, D.V.V. \& ALMEIDA-CORTEZ, J. 2009. Galhas entomógenas em um fragmento urbano de Mata Atlântica no centro de endemismo de Pernambuco. Rev. Bras. Bioci. 7(3):240-244.

JULIÃO, G.R., AMARAL, M.E. \& FERNANDES, G.W. 2002. Galhas de insetos e suas plantas hospedeiras no Pantanal Sul-Matogrossense. Naturalia 27(1):47-74. 
MAIA, V.C. \& OLIVEIRA, J.C. 2010. Galhas de insetos da Reserva Biológica Estadual da Praia do Sul (Ilha Grande, Angra dos Reis, RJ). Biota Neotrop. 10(4): http://www.biotaneotropica.org.br/v10n4/en/abstract?i nventory+bn04110042010

MAIA, V.C. 2001. The gall midges (Diptera, Cecidomiiydae) from three restingas of Rio de Janeiro State, Brazil. Rev. Bras. Zool. 18(2):583-629. http://dx.doi.org/10.1590/S0101-81752001000200028

MAIA, V.C. 2005. Catálogo dos Cecidomyiidae (Diptera) do Estado do Rio de Janeiro. Biota Neotrop. 5(2): http://www.biotaneotropica.org.br/v5n2/ pt/abstract?inventory+BN00805022005

MAIA, V.C., MAGENTA, M.A.G. \& MARTINS, S.E. 2008. Ocorrência e caracterização de galhas de insetos em áreas de restinga de Bertioga (São Paulo, Brasil). Biota Neot. 8(1): www.biotaneotropica.org.br/v8n1/en/ab stract?inventory+bn02408012008.

MENDONÇA, M.S. 2007. Plant diversity and galling arthropod diversity searching for taxonomic patterns in an animal-plant interaction in the neotropics. Bol. Soc. Argent. Bot. 42(3-4):347-357.

MOREIRA, R.G.; FERNANDES, G.W., ALMADA, E.D. \& SANTOS, J.C. 2007. Galling insects as bioindicators of land restoration in an area of Brazilian Atlantic Forest. Lundiana. 8(2):107-112.

OLIVEIRA, J.C. \& MAIA, V.C. 2005. Ocorrência e caracterização de galhas de insetos na restinga de Grumari (Rio de Janeiro, RJ, Brasil). Arq. Mus. Nac. 63(4):669-675.

PRICE, P.W., ABRAHAMSON, W.G., HUNTER, M.D. \& MELIKA, G. 2004. Using gall wasps on oaks to test broad ecological concepts. Conserv. Biol. 18(5):1406-1416. http://dx.doi.org/10.1111/j.15231739.2004.00547.x
PRICE, P.W., FERNANDES, G.W., LARA, A.C.F., BRAWN, J., GERLING, D., BARRIOS, H., WRIGHT, M.G., RIBEIRO, S.P. \& ROTHCLIFF, N. 1998. Global patterns in local number of insect galling species. J. Biogeogr. 25(3):581-591. http://dx.doi.org/10.1046/j.13652699.1998.2530581.x

SANTOS, J.C., ALMEIDA-CORTEZ, J.S. \& FERNANDES, G.W. 2011. Diversity of gall-inducing insects in the high altitude wetland forests in Pernambuco, Northeastern Brazil. Braz. J. Biol. 71(1):47-56. http:// dx.doi.org/10.1590/S1519-69842011000100008

SHORTHOUSE, J.D., WOOL, D. \& RAMAN, A. 2005. Gall-inducing insects - nature's most sophisticated herbivores. Basic Appl. Ecol. 6(5):407-411. http://dx.doi.org/10.1016/j.baae.2005.07.001

SILVA, J.M.C. \& CASTELETI, C.H.M. 2003. Status of the biodiversity of the Atlantic Forest of Brazil. In The Atlantic Forest of South America: biodiversity status, threats, and outlook (C. Galindo-Leal \& I.G. Câmara. eds). Center for Applied Biodiversity Science and Island Press, Washington, p.43-59.

SILVA, P.S.D., KNOECHELMANN, C.M., TABARELLI, M. \& ALMEIDACORTEZ, J.S. Richness of gall morphospecies along a secondary successional gradient of Atlantic Forest in northeastern Brazil. Rev. Bras. Bioci. 9(3):270-277.

TABARElli, M., PINTO, L.P., BEDÊ, L., HIROTA, M. \& SILVA, J.M.C. 2005. Challenges and opportunities for biodiversity conservation in Brazilian Atlantic forest. Conserv. Biol. 19(3):695-700. http://dx.doi. org $/ 10.1111 / \mathrm{j} .1523-1739.2005 .00694 . x$

TABARELLI, M., SIQUEIRA FILHO, J.A \& SANTOS, A.M.M. 2006. A floresta Atlântica ao norte do Rio São Francisco. In Diversidade biológica e conservação da floresta Atlântica ao norte do Rio São Francisco (K.C. Pôrto, J.S. Almeida-Cortez \& M. Tabarelli, eds). Ministério do Meio Ambiente, Brasília, p.21-35. Coleção Biodiversidade. 